\title{
The Mapping of Mosque Community to Improve Mosque Engagement in Community
}

\author{
Kholid Haryonoa), Elyza Gustri Wahyuni, and Farhan Mozart Aditya Fahreza
}

\author{
Department of Informatics, Universitas Islam Indonesia, Yogyakarta, Indonesia \\ a)Corresponding Author: kholid.haryono@uii.ac.id
}

\begin{abstract}
The Mosque in the Prophet Muhammad SAW era had a strategic role. The role is to be a solution and provide prosperity for the Muslims in particular and the surrounding community in general. Currently, the mosque plays a narrower role. It is a provider of facilities for pilgrims to carry out routine worship. In order for this role to increase, the mosque administrator, called DKM (Mosque Prosperity Council), must know his congregation more closely so that he knows what is needed and then comes to provide solutions. This study aims to create and implement an information system to manage congregational data to improve the role of mosques in the community. The main material that was obtained and prepared was data on residents around the mosque and the stakeholder needs (leaders of organizations around the mosque such as the heads of hamlet (RW), neighbourhood (RT), and youth organizations). The citizen data and stakeholder needs are used to develop the system. Because the specifications of the requirements can change during system development, the development method chosen is the prototyping method. There are two main outputs of this activity, namely the availability of a congregational data mapping application, and the installation of internet network infrastructure at the mosque. The two outputs in their implementation have proven to be beneficial for the congregation and the surrounding community. The information system provides improved service quality to pilgrims and residents in various activities such as zakat and qurbani. Meanwhile, Internet infrastructure provides new hope in easing the burden of community quotas and bringing children closer to the mosque.
\end{abstract}

Keywords: Mosque information system, Mosque prosperity, Mosque internet, Congregational data mapping

\section{INTRODUCTION}

Recognizing the community around the mosque is the key to managing a good mosque. Moreover, the majority of the community's religion is Islam. A good mosque is a prosperous mosque(Siskawati, Ferdawati, \& Surya, 2016). The prosperity is shown through the number of worshipers who worship in the mosque. The prosperity also means the ability of DKM to provide a solution for community's problems. Therefore, it is important to realize an improve in the prosperity of the mosque from both sides(Nurfatmawati, 2020).

The Hidayatul Falah Mosque, located in the Purwomartani village of Kalasan, Sleman, Yogyakarta, is the only mosque in the hamlet. Currently, the member of DKM is struggling to improve. They are young people with a strong spirit. The role of management is also large in the community, both in the Women Farmers Group (KWT), the management of RT and RW, as well as various other associations. How to strengthen cooperation and the role of mosques in community organizations and or society in general is important.

There are two big problems being faced: internal and external problems. The internal problem is the DKM does not know their congregation, how many worshipers (male, female, age level), including those who have been to the mosque and those who have not, who can read the Koran and not, who have sacrificed and have not, hajj, zakat, Friday prayers, and so on. Even small problems such as if there are pilgrims who are sick and need a certain blood type, the mosque has not been able to provide a solution because it does not know who the congregation has the right blood type. While the external problem is related to community data which is often a problem when it comes to activities by the mosque. For example, when distributing the meat of the sacrificial animal, zakat fitrah, and zakat mal. 
There has been an initiative to improve the data in order to increase the role of mosques by collecting data on congregations. The data has been recorded in the form of an Excel file. The source of the data was obtained from documents held by the village apparatus (RT). Unfortunately, access to the data is still limited to the DKM's computer and posted on the bulletin board in printed form in the wall of mosque.

This limited access leads to communication bias and even to the assumption of mutual suspicion. Therefore, this data can be increased with the help of computer applications so that information can be more easily read, retrieved, and used to increase the prosperity of the mosque and the prosperity of the congregation(Abdulloh Azzama, 2019). This will support various needs, both internal to the mosque and the need for collaboration with institutions outside the mosque. For example, when the head of the RW was asked for data on elementary school children whose parents were underprivileged to offer scholarships, the RW asked for data from the mosque because the data for children of that age were all recorded as TPQ (Quran Education Park) students. In the other name, TPQ was known by called TPA(Ridhwan et al., 2020). In addition, the member of DKM who are relatively young have good literacy in using computer applications. This is an opportunity to improve computer-based mosque governance.

This agenda is aimed at exploring the problems faced by mosques related to the management of congregational data and collaboration with other organizational units in the community. Looking for solutions to the problems found and offering solutions in the form of developing information systems and providing related infrastructure so that data for pilgrims and the community can be better managed.

\section{METHOD \& DATA SOURCE}

There are two sources of data for this activity. First, data on the community around the mosque as a whole, without distinguishing ethnicity, race, and religion. Second, information needs are obtained from stakeholders such as DKM, government officials around the mosque, youth organizations, and women's activists. The goal is to provide data and information that can be accessed more easily and usefully for stakeholders. The solution given is to create an application that has the main task of processing data into information to achieve that goal. The method used follows the general information system development method. The stages are: needs analysis, system design, system development, deployment, training or system implementation, socialization to the community through local government officials(Pressman, 2001).

\section{Analysis Requirement System}

The main activity in this activity is to make direct observations to the location to explore problems and identify system requirements. At the time of observation, interviews were also conducted with DKM to obtain the desired needs in the application(Creswell, 2014). The activities carried out are:

- Observation, namely making direct observations to the location, active in dialogue and participating in routine activities.

- Interviews and FGDs (Focus Group Discussion) with the core of DKM members and youth organizations.

The results of observations and interviews have identified several problems as shown in Table 1

Table 1. List of problems found

\begin{tabular}{llll}
\hline No & Priority Problem & Amount & Justification \\
\hline 1 & Identify the data & 0 (already exists and & Recognizing the completeness of data \\
needs of the & is not complete in & needs is the key to the success of \\
congregation and & variables/fields for & good congregation and community \\
& the community & database needs) & data management. \\
2 & $\begin{array}{l}\text { Application facilities } \\
\text { for easy access to }\end{array}$ & $\begin{array}{l}0 \text { (already in } \\
\text { spreadsheet form and }\end{array}$ & $\begin{array}{l}\text { It is necessary to make applications } \\
\text { that facilitate access and make it }\end{array}$ \\
\hline
\end{tabular}




\begin{tabular}{|c|c|c|c|}
\hline & $\begin{array}{l}\text { data and information } \\
\text { of pilgrims }\end{array}$ & $\begin{array}{l}\text { locally with very } \\
\text { limited access) }\end{array}$ & $\begin{array}{l}\text { easier for administrators to be able to } \\
\text { recognize the field of da'wah so that it } \\
\text { can be used as a basis for better } \\
\text { decision making and making activities. }\end{array}$ \\
\hline 3 & Access Internet & 0 (not yet available) & $\begin{array}{l}\text { The information system needed is } \\
\text { web-based and online, so internet } \\
\text { access is needed. In addition, some } \\
\text { mosque youth activities such as online } \\
\text { learning also require internet access }\end{array}$ \\
\hline 4 & $\begin{array}{l}\text { Digital literacy } \\
\text { training for the } \\
\text { implementation of } \\
\text { the congregational } \\
\text { data mapping } \\
\text { application }\end{array}$ & $\begin{array}{l}4 \text { (there are } 2 \\
\text { members of DKM and } \\
2 \text { youths who are able } \\
\text { to operate computers } \\
\text { and gadgets well }\end{array}$ & $\begin{array}{l}\text { This literacy is important to improve } \\
\text { the ability to use applications for } \\
\text { better data management of pilgrims }\end{array}$ \\
\hline 5 & $\begin{array}{l}\text { Socialization of } \\
\text { congregational open } \\
\text { data to collaborate } \\
\text { with community } \\
\text { officials }\end{array}$ & $\begin{array}{l}4 \text { ( } 1 \text { head of RW, } 2 \\
\text { head of RT, } 1 \text { head of } \\
\text { KWT) }\end{array}$ & $\begin{array}{l}\text { After the application is ready to be } \\
\text { implemented and the data has been } \\
\text { entered, it is necessary for apparatus } \\
\text { and community group leaders to be } \\
\text { able to use the information in order to } \\
\text { increase collaboration between } \\
\text { mosques and wider community } \\
\text { leaders. }\end{array}$ \\
\hline
\end{tabular}

Based on the results of the identification of the problem, further investigation of what system requirements are needed. The main points of need were identified as follows:

a. The system must be usable by DKM, RW heads, RT heads, youth, and KWT (women farmer groups). Hereinafter known as role or user group.

b. The system can record and store all population data based on KK (family card)

c. The system can record the house number of each household and identify the number of households per house.

d. The system can record the economic level of each family based on KK

e. The system can record the age of the population automatically

f. The system can record basic personal data such as gender, blood type, education, expertise, and status of residence whether domiciled or currently wandering

g. The system can record a person's worship status whether they have prayed, zakat, fasted, Friday prayer, and participated in the sacrifice during Eid al-Adha

h. The system can record a person's ability whether he can read the Quran, Iqra, or Latin.

All of these needs are related to the activities that have been carried out so far. For example, once the head of the RW and RT asked for population data with a certain age range, a certain economic level for the offer of village scholarships and social assistance, blood types for people who are sick and need certain blood types, and so on. Youth often need a list of residents' names for making invitations if there are village events that have been recorded manually. This is important because it is often misdelivered or left behind. KWT requires the number of women with various age ranges in the mosque area. Likewise, Takmir often requires data on congregations and residents for the purposes of distributing zakat, distributing sacrificial meat, training and assisting community worship, and so on.

\section{System Design}

System design activity is the activity of translating the results of the needs analysis into three forms, namely business process design, database design, and interface design. In this design, 
the business process design is shown in the form of a Usecase Diagram as shown in Figure 1. As for the database design, it will describe the data groups and supporting data needed. The database design here does not show the relationships between tables to make it easier to understand the meaning. While the interface will be discussed at the point of implementation.

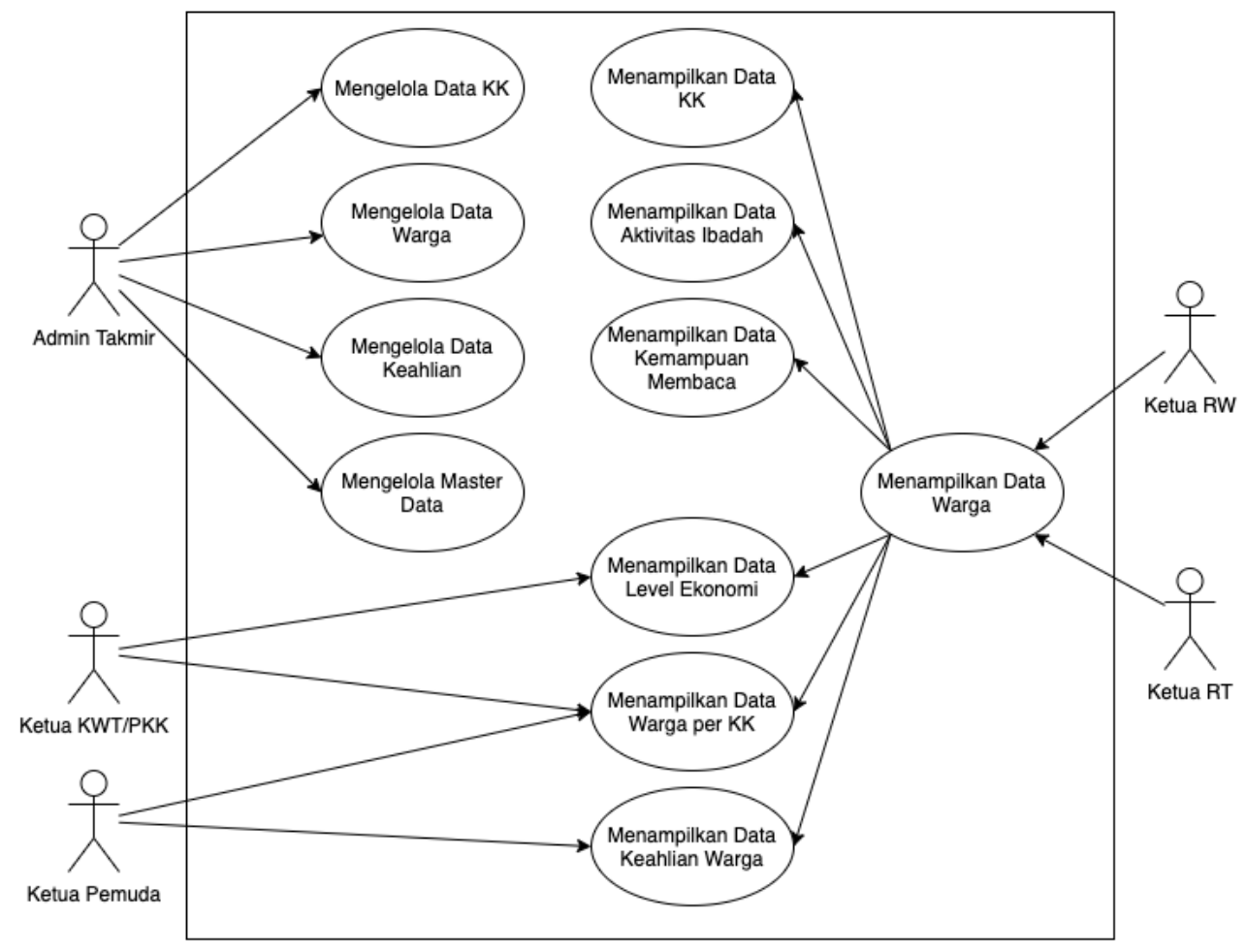

Figure 1. Use Case Diagram of the mosque congregation mapping system

Figure 1 shows the five roles that will use the system, namely DKM as admin, head of RW, head of RT, head of KWT/PKK, and head of youth organizations. Each role has different access rights according to their respective roles. Details of the features and access rights of each role are shown in Table 3.

The database design in this paper will mention the main tables in the system, the attributes of each table, and justification for the attributes that contain the reasons why these tables and attributes are needed. This is shown in Table 2

Table 2. Database Contents

No Main Tables Attributes and Justification

1 Family Card (KK) Attributes: number of $\mathrm{KK}$, family head name, house number, economic level, RW, RT.

Justification: KK is the parent of all citizen data. This data is used in many activities such as distribution of aid per household, distribution of zakat, knowing the economic level, and distribution of invitation letters. the data must be filtered by region, namely RW and RT. The house number is used for line sorting in order to speed up and make it easier to carry out the distribution needs of various things.

2 Citizen Master Data Attributes: KK_number, NIK, name, nickname, address, TTL, gender, blood type, religion, expertise, economic level, last education, occupation, ability to worship (already prayed, sacrificed, umrah, hajj, friday, regular recitation, zakat, fasting), the ability to read (read the Quran, lqra, and Latin).

Justification: It is basic data that records the basic identity of each resident. KK and NIK numbers are used to find out the number of people per household which are commonly used for 
3 Data References

4 Configuration distributing sacrificial meat and social assistance. Place of Birth Date is used to determine age so that the age level is known (toddler, adolescent, adult, old, and senior). Gender to determine the composition of the population based on gender. Blood type to more quickly find potential donors if there are residents and pilgrims who are sick and need a certain blood type. Religion for the distribution of sacrificial meat where Muslim families are divided per person and non-Muslims are divided equally per household. Also, to find out the composition of religion in the community around the mosque as an ease in preaching. Expertise is often used to find certain skills when there are events or activities of residents/mosques. Education, employment, economic level are also often requested by the village officials. Worship activities to find out the field of da'wah, who has prayed or not and so on so that da'wah becomes more focused. The same goes for reading activities. The program to eradicate illiteracy by the mosque will be difficult to do without knowing the map.

Attributes: religion (religious code, religious name), Education, economic level, occupation, RW, RT, house number, and expertise.

Justification: master data is used to make it easier to filter data consistently. For example, filtering religion between Buddhism like "budha" or "buddha" can be different. With master data, filtering becomes more consistent because it is done by selecting, not writing down manually.

Attributes: user and password. Justification: is a mandatory table to provide data security guarantees from unexpected misuse of personal data.

\section{System Development}

The system was developed using the prototyping method(Dennis, Wixon, \& Roth, 2009). This method is suitable for systems whose needs are not clear from the start so that changes are possible at each stage. These changes can be in the form of additional needs due to the emergence of new ideas that have not been thought of before, and so on until the system has been accepted by stakeholders and can provide benefits. This information system was developed based on the web because in addition to being easy to access and open on various devices, it is also easier to develop. The language used is PHP with the Laravel framework. This was chosen because at the time of development, this framework was among the best and superior compared to the others(Appkey, 2020). One of the main views of the developed system is shown in Figure 2 


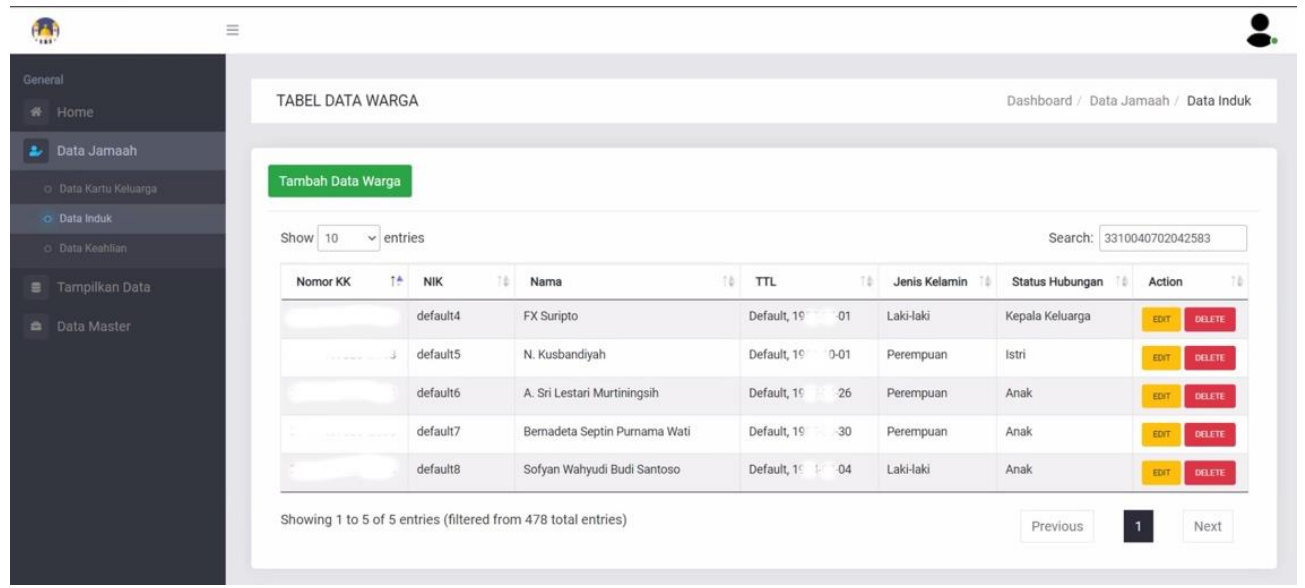

Figure 2. Citizen data interface

The system is developed based on user roles in Figure 1. Each role has access rights to related features only. One of the main features, for example in the admin role (DKM) is managing citizen data. This feature is shown in Figure 2. Citizen data is the most important because the main purpose of the DKM is to get to know the congregation and the community around the mosque so that their da'wah fields are well identified. In that way, the mosque can contribute to a solution for the congregation in particular and society in general. Without knowing the people one by one, the da'wah effort becomes undirected and less than optimal. Through this citizen data management feature, the admin can add residents and immediately group them by family. Therefore, it can be seen in Figure 2 the column "relationship status". Apart from adding, data can also be changed and deleted if something goes wrong. The features of each role are shown in Table 3.

Table 3. Features of each role

\begin{tabular}{lll}
\hline No & Role & \multicolumn{1}{c}{ Feature and Facilities } \\
\hline 1 & Admin (DKM) & As the main manager of citizen and congregation data. This role can \\
& manage KK data, resident parents, resident expertise data, all master \\
& data such as RW, RT, religion, education, blood type, religious ability, \\
& reading ability, and house data. Admin can also open the entire view of \\
& citizen and congregation data per data group. It is able to display data \\
& that is divided into several groups, namely displaying residents based \\
& on RW, RT, religion, blood type, and all existing master data along with \\
& the combination of filters such as displaying \\
& As a user of information, especially related to citizen data. This role \\
& can communicate with data in the form of a list or table. The \\
& communication uses filtering and searching techniques. Filtering is \\
& displaying data according to certain data groups such as displaying \\
& only certain household data, certain economic levels, certain blood \\
& groups, certain ages, certain genders, and so on. While searching is \\
& doing filtering based on fragments of letters and searching for all the \\
& contents of the data displayed.
\end{tabular}

3 Head of RT

As a user of special information for residents on a smaller scope, specifically at the Neighbourhood Association level. This role has access rights like the head of the RW but only in the scope of the RT.

4 Head of KWT As users of special information for mothers and female citizens as a \& PKK whole. Two women's organizations in the mosque area are KWT (Group of Women Farmers) and PKK (Family Welfare Empowerment). This role can display all female citizens with filtering capabilities such as the access rights of the RW head.

5 Head of youth As a user of information from youth organizations. The youth admin organization has the role of browsing information related to the data of citizens 
under the age of 30 and unmarried. How many young people, young women, whose age is between so and so and so on.

\section{System Deployment}

System installation or deployment is the process of placing the system into a virtual network infrastructure which is also known as hosting and then assigning an alias to make the address more accessible, which is called a domain name. The system is hosted on a hosting company in Jogja that provides a two-year or three-year rental promo. More importantly, this hosting company gets testimonials from various software houses. In addition, several campuses also use it so that it is quite a recommendation for use. The leased domain is http://masjidhidayatulfalah.org This address will later become the main page of the mosque portal. In addition to the congregational data mapping feature, icons to enter various other mosque services such as zakat services, sacrifice management, Ramadan programs, and so on will also be filled. The interface icon is shown in Figure 3

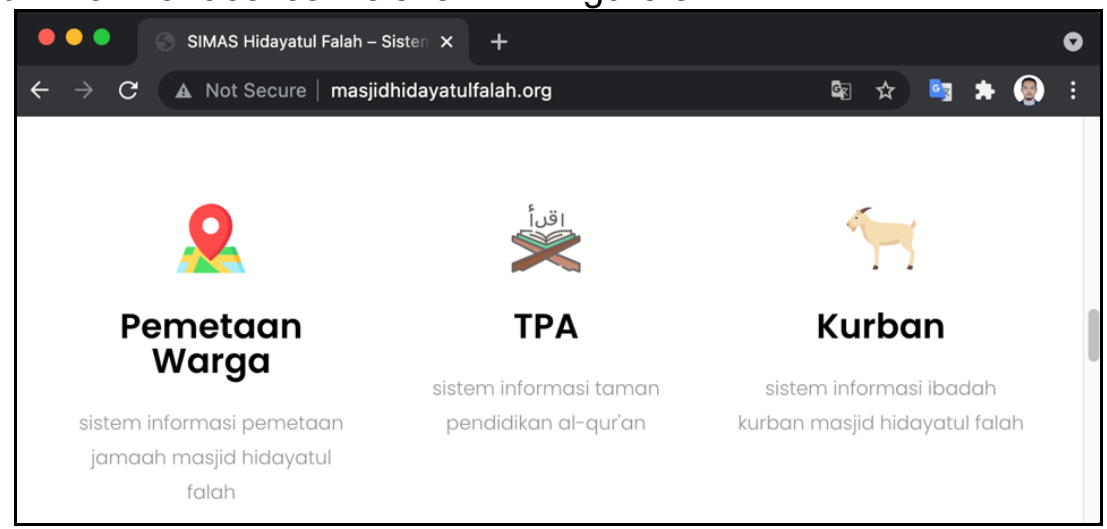

Figure 3. Icons in main interface system

As a place of public service, as the priority problems identified in Table 1, namely there is no internet connection at the mosque. At this stage there is simultaneously an offer of free internet from an internet service provider company that will provide free services for six months. Actually, this is intended as a public facility. The opportunity was taken by the DKM and internet access was installed in the mosque. The internet capacity obtained is $10 \mathrm{Mbps}$. The installation activity is shown in the image in the attachment of this paper.

\section{System Training and Socialization}

System training is carried out only for operators who have transaction facilities such as input, edit, delete, and organize data, namely DKM and youth management. Meanwhile, socialization or system demos were carried out to other roles such as the head of the RW, RT, and KWT with features that were only able to display reports and information. For this role training is not required and is only given in the form of socialization activities.

Socialization activities are the stage of introducing the system to users in this case stakeholders who use information and communicate with the system in utilizing information. These roles include the head of the RW, RT, head of KWT/PKK, and head of youth organizations. The socialization is carried out separately by coming to the house in question, showing the method, and practicing it using their respective devices.

\section{RESULTS}

In this section, the resulting output will be described. The intended output is related to the output of the problems mentioned in Table 1 regarding priority problems. Table 1 briefly mentions five partner problems, namely: 1) how to identify the data needs of pilgrims and the community, 2) how to provide application facilities for easy access to information, 3) how to provide internet access, 4) how to provide system training to stakeholders, and 5) how to socialize the use of open data to stakeholders. Each problem will describe the resulting output. 
The first problem is how to identify the data needs of the congregation and the community. The youth of the mosque have collected data through a copy of the document from the RT apparatus. The document by the youth of the mosque was recorded in the Spreadsheet list and became the initial data of residents. The output obtained is a list of residents per KK and NIK whose attributes are taken from the complete KK and NIK documents.

The second problem is how to provide application facilities for easy access to information. An information system has been developed which is assisted by a programmer from Department of Informatics undergraduate program students, UII. Software development uses the Prototyping method to make it easier to explore stakeholder desires. The output is in the form of an application that can be accessed through the address: http://masjidhidayatulfalah.org. The user role of the application consists of five, namely: the DKM as admin, the head of the RW, the head of the RT, the head of the PKK/KWT, and the Head of Youth Organization.

The third problem, how to provide internet access. It is planned that internet access will be registered independently by the mosque to the internet provider. However, before the month of Ramadan 2021, there is a provider that is installing a network to enter the village so that mosques as public facilities get a free connection quota for the first six months. The output of this activity is that internet access is available at the mosque and can be accessed by the congregation or the general public.

The fourth problem is how to provide system training to stakeholders. This training is especially for data managers. The manager function in the application is a member of DKM who is also assisted by the youth of the mosque. The training is carried out at the mosque after the application is hosted and can be accessed via public channels (internet). The output of this activity is that the admin assisted by the youth has been able to operate the application as well as manage data on the system independently.

The fifth problem is how to socialize the use of open data to stakeholders. Stakeholders in question are users of information, namely the head of the RW, the head of the RT, the head of the KWT, and the head of the youth. The socialization was carried out by inviting stakeholders to the mosque and demonstrating the system. Participants can directly access through their respective devices.

All outputs in this series of community service activities have been achieved as targeted. The photos of the activities are shown in the attachment at the bottom of this paper. In the next discussion sub-chapter, will specifically discuss the outcome of each problem output in this activity.

\section{DISCUSSION}

The previous results section discussed the output of each activity. In this section, we will discuss the outcome of each of the resulting outputs. Outcome emphasizes more on the impact of implementation for users, people, or organizations. The resulting impacts are as follows.

The list of residents in the mosque area has been compiled in a complete spreadsheet file. The data includes KK No., NIK per KK including area of residence (RW and RT), personal completeness such as gender, blood type, economic level, and expertise. Data verification is carried out with the head of the RT and all member of DKM. For the first time, this data was used in the withdrawal of zakat fitrah, distribution of zakat fitrah, distribution of gifts for widows, "takbir" competitions, and helping the scheduling of village guard officers when spraying disinfectants in the early days of the COVID-19 pandemic. Recent data states that the total population in the mosque area consists of 160 families and 479 residents. The composition of men and women is almost equal. 231 men and 248 women. The total number of Muslims is 428 and this is the focus of services for the congregation of the mosque. The number of nonMuslims is 51 people.

A web-based application for mapping congregational and community data has been implemented through the website http://masjidhidayatulfalah.org. For the first time this application was used in sacrificial activities, especially to determine the proportion of the distribution of sacrificial meat. Previously, the distribution of meat was done evenly per household. If you get a total of $400 \mathrm{Kg}$ of beef with a total of 160 families, then each family will 
get $300 / 160=1,875 \mathrm{Kg}$ of beef. Based on the results of the previous year's evaluation, this distribution was considered uneven because there were KK with only one person (widow) and there were also many with up to 10 people. In order to be proportional, through this application the dividing factor can be calculated based on the number of members per family. This year (2021) it is determined that those who are entitled to receive are family members with an age range of over 7 years. So, there are 356 people. So, per person gets $300 / 356=0.84 \mathrm{Kg}$. If a household consists of 10 people, it will get $8.4 \mathrm{Kg}$. After this is applied, the evaluation results show a $100 \%$ satisfaction level with a $0 \%$ complaint rate. Unlike the previous year, there were always problems, especially regarding the feeling of being unfair. In addition, stakeholders who saw the application showed great hope that this could help various problems with congregational data and population at the village level. One other problem that often occurs is that in the process of sending invitations to residents for an event in the village, there are always families or residents who are left behind that are not invited by accident. This happened because the order of the houses of the residents was not clear, the names of the residents were different between their nicknames and the names of their ID cards. Another thing related to the importance of data is in the process of distributing social assistance, distribution of Friday blessing assistance from the blessing Friday community, and so on.

The third output is internet access that has been installed in the mosque. Initially, there were complaints from some parents and congregation that children were busy going to the mosque just to play online games. Gradually, the socialization of the benefits of the internet to the congregation was carried out and they increasingly understood the needs of children. One of the socializations was carried out during "tadarusan" (reading the Koran together) in the month of Ramadan. It was also conveyed after Friday prayers when many worshipers enjoyed lunch at the mosque which were obtained from the Friday blessing community. The socialization reaped good results. Apparently, this pandemic has reduced the purchasing power of parents for their children who are studying online. So, the mosque's Wifi is the solution. Although the benefits are still not proportional between learning activities and playing games. In addition, the previous children's playground at the village intersection has now been moved to a mosque. As a result, many children began to pray in congregation when it was time for prayer. The results of the evaluation provide recommendations for empowering mosque youth and youth so that they can guide children to study and do assignments at the mosque by using the mosque's Internet access.

After training using information systems to DKM officers and several youths. Data management is now easier than ever. Previously, data updates were carried out when there would be an event involving citizen data. With the system, all users can immediately update and see changes in real time. If there are findings of changes in data in the field, coordination is carried out via social media so that it can be carried out more quickly and confirmed changes can be directly changed via the application. After the admin is able to operate the system independently, the next follow-up is data collection and updating of data, especially data related to people's worship and reading skills. The system has provided worship columns to store those who have or have not prayed in congregation, fasting, umrah, hajj, zakat, sacrifice, can read latin letters, iqra/hijaiyah letters, and the Koran. Through this data, it is expected to be useful information for determining da'wah activities to the community in a more targeted manner

The fifth output is outreach to stakeholders, namely the head of the RW, the head of the RT, the head of the KWT/PKK, and the youth leader. The response from the socialization has given great hope to realize a community data around the mosque and increase collaboration between organizations in the village. Collaboration has been done sporadically and without good planning. With this data, stakeholders hope that all village leaders can work together in improving welfare and a good life in the community. One thing that has not been touched by many organizations other than poverty is the moral assistance of children and adolescents. It is hoped that through this data, children and adolescents can be grouped for teaching and learning activities and the Koran through TPQ (Quran Education Park) activities. It is become 
known that who has reached where and what is lacking will be easier to monitor together. So, that the synergy between the mosque and the community will be better.

\section{CONCLUSIONS And RECOMMENDATIONS}

The purpose of this community service is to increase the involvement of mosques in the community through better mapping of congregational data and citizen data. In addition, providing free internet services to the public in order to meet the high internet needs during the Covid-19 pandemic, especially for school children and teenagers, has been considered very helpful. The conclusion from the implementation of the congregation data mapping shows two important outputs, namely the development of the congregation data mapping application and the provision of internet access. The information system has helped one of the community's biggest activities, namely the celebration of Eid al-Adha by changing the distribution of meat to be more proportional. In addition, the system features recognized by stakeholders as useful in increasing collaboration between organizations in the village, both Muslim and non-Muslim. The benefits of providing an Internet network at mosques have been able to ease the burden of quotas for parents, help children gather in mosques and participate in congregational prayers, and have the potential to provide more intense mentoring in learning and reciting activities by mosque youth and youth.

Some further suggestions for this activity are, firstly it is necessary to monitor and develop a dashboard from the available data so that the information produced is of higher quality and easy to read and understand by stakeholders. Improving the quality of information is expected to contribute to better decision making. Regarding the Internet that has been installed in the mosque, it is necessary to carry out more organized mentoring activities for children in doing school assignments at the mosque so that children do not spend too much time playing games around the mosque.

\section{ACKNOWLEDGMENTS}

This service activity is supported and financed by the Islamic University of Indonesia through the UII Directorate of Research and Community Service (DPPM) in the Internal Service Grant program with the Outstanding Community Service scheme. Therefore, the author as the community service team expresses many thanks to UII, especially DPPM as the responsible sector and facilitator of this activity. Thanks, are also conveyed to the management of the Hidayatul Falah mosque who have been welcoming and cooperative during this activity.

\section{REFERENCES}

Abdulloh Azzama, M. (2019). Manajemen Masjid Jogokariyan Yogyakarta Sebagai Pusat Kegiatan Masyarakat. Komunika: Journal of Communication Science and Islamic Da'wah Volume 3 (1), 2019, 3(1), 197-205.

Appkey. (2020). Mengapa Framework Laravel Lebih Unggul Dibandingkan Framework yang Lainnya? Berikut Alasannya!

Creswell, J. W. (2014). Research Design, Qualitative, Quantitative, and Mixed Methods Approaches (Fourth Edi). SAGE Publication.

Dennis, A., Wixon, B. H., \& Roth, R. M. (2009). System Analysis and Design (Fifth). New: Wiley \& Sons.

Nurfatmawati, A. (2020). Strategi Komunikasi Takmir Dalam Memakmurkan Masjid Jogokariyan Yogyakarta. Jurnal Dakwah Risalah, 31(1), 21. https://doi.org/10.24014/jdr.v31i1.9838

Pressman, R. S. (2001). Software Engineering - A Practitioner's Approach (Fifth). New York: Thomas Casson.

Ridhwan, R. M., Susilo, M. W., Bimasakti, T. E., Chandra, R., Alantaqi, A., \& Sugito, S. (2020). TPA Punakawan: Sarana Meningkatkan Kecerdasan Spiritual Anak Berbasis Kearifan Lokal. ABDIMAS: Jurnal Pengabdian Masyarakat, 3(2), 230-235. https://doi.org/10.35568/abdimas.v3i2.456

Siskawati, E., Ferdawati, \& Surya, F. (2016). Pemaknaan Akuntabilitas Masjid: Bagaimana Masjid dan Masyarakat Saling Memakmurkan? Jurnal Akuntansi Multiparadigma, 7(1), 70-80. https://doi.org/10.18202/jamal.2016.04.7006 


\section{APPENDIX}

This appendix contains mosque activities related to the management of congregational data management and the procurement of internet network infrastructure carried out in the context of carrying out these activities.

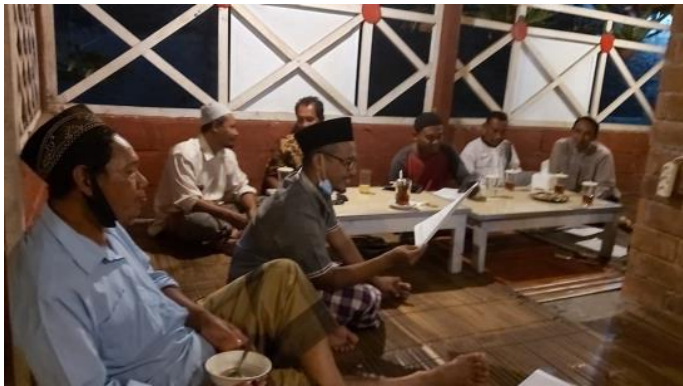

(a) Activity planning meeting

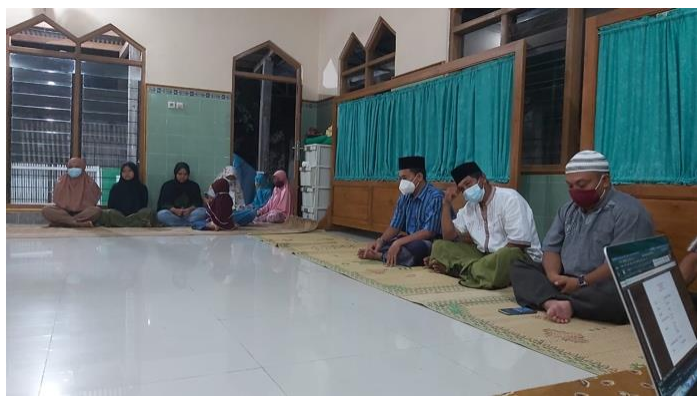

(c) Requirement system analysis with woman stakeholder

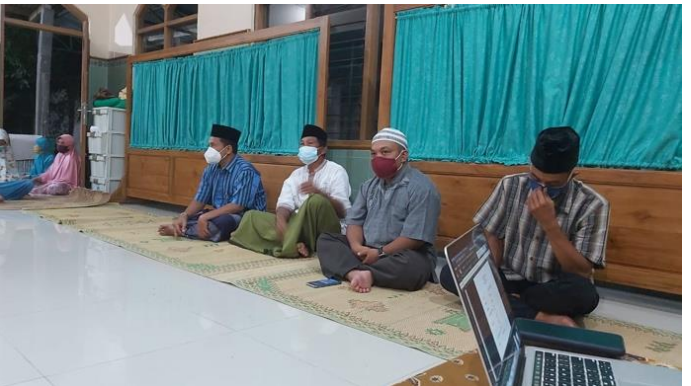

(b) Requirement system analysis with stakeholder

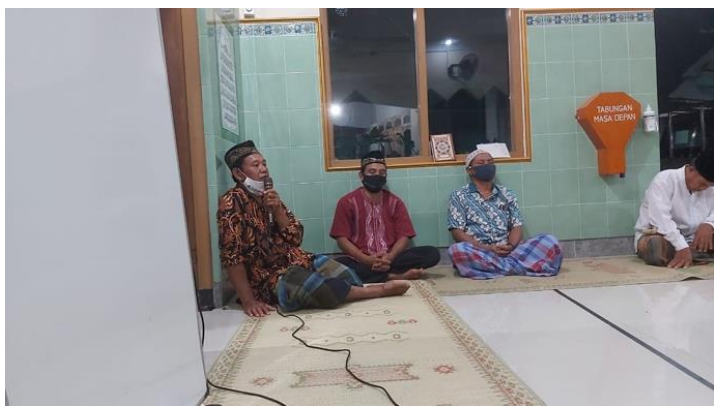

(d) The opening speech of the chairman of takmir in a meeting with stakeholders

Figure 4. System requirements planning and analysis activities

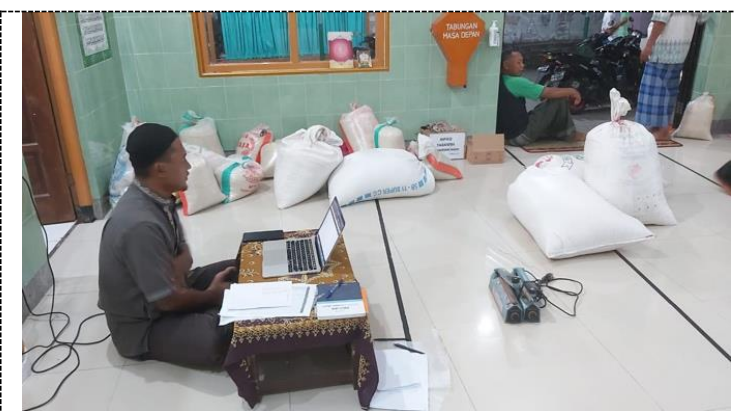

(a) Data recapitulation of zakat receipts and distribution plans

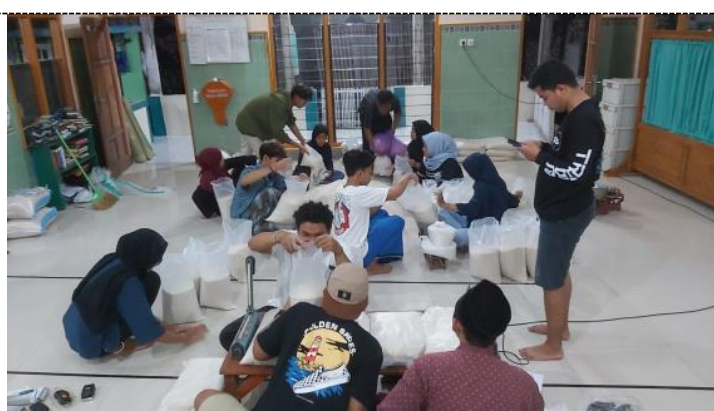

(b) Weighing rice before distribution 


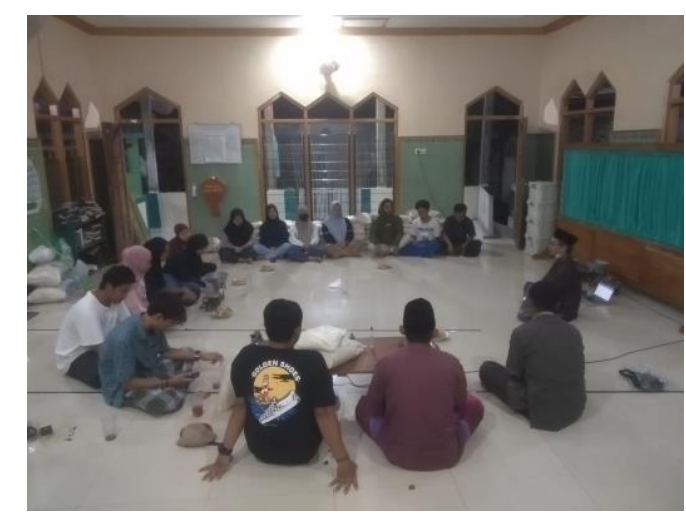

( c ) Distribution preparation data check

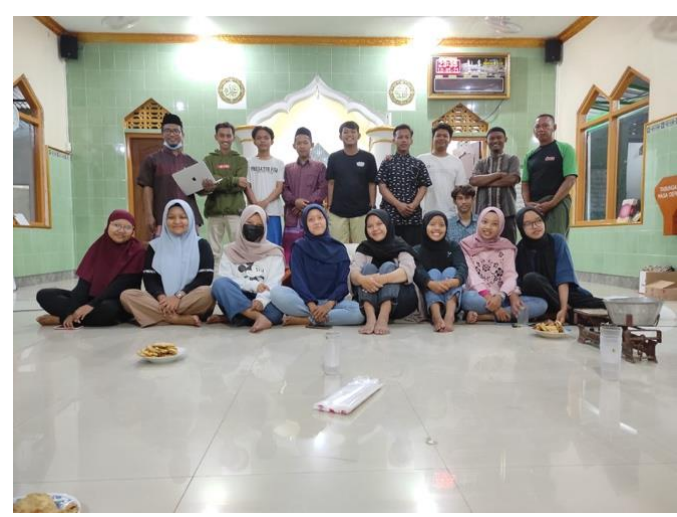

(d) Closing of zakat distribution activities

Figure 4. Use of data on zakat management
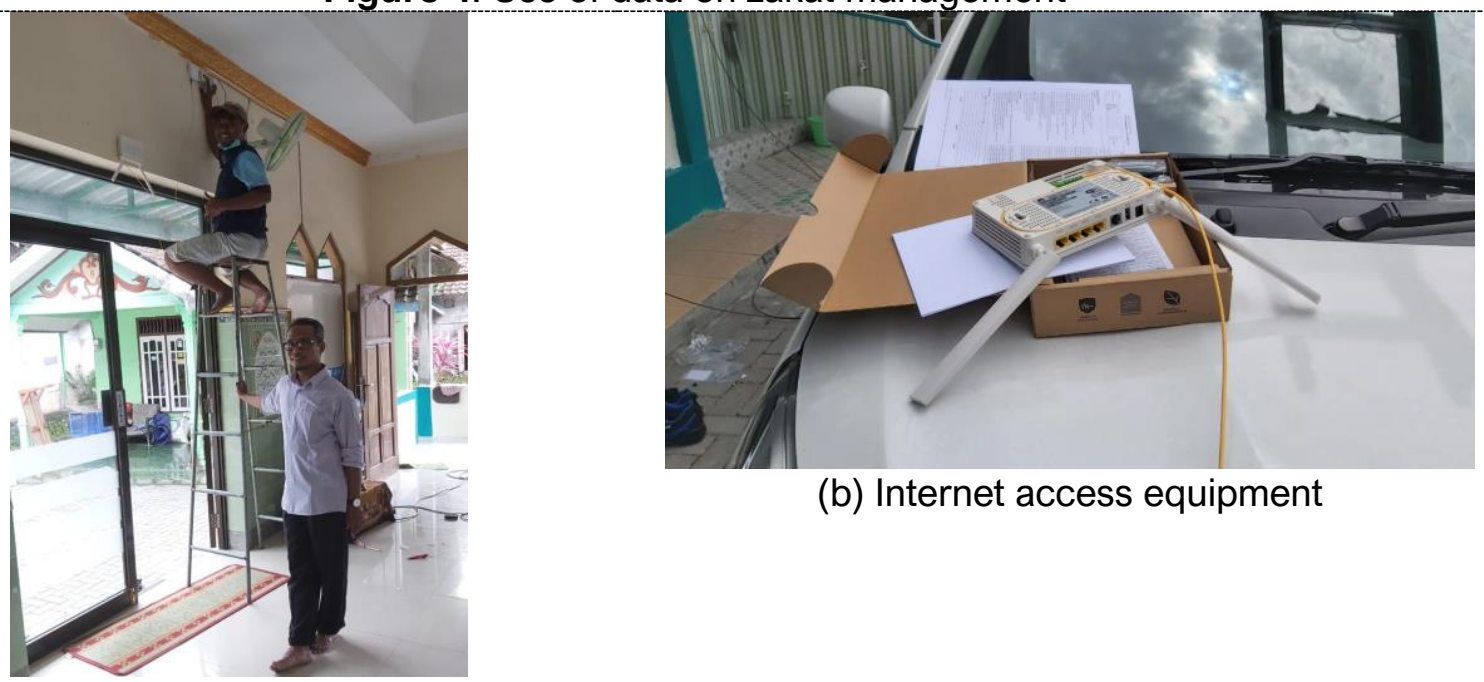

(b) Internet access equipment

Figure 5. Internet access installation 